\title{
Current Updates on Covid-19 Vaccine Research and an Overview of Therapeutic Drug Research
}

\author{
M. Oviyaasri ${ }^{1}$, M. Manjuladevi ${ }^{2}$, S. Kalaiselvan ${ }^{3 *}$ and U. Haripriyan ${ }^{4}$ \\ ${ }^{1}$ Graduate at National University of Ireland, Galway, Ireland. \\ ${ }^{2}$ Department of Chemistry, SNS College of Technology, Coimbatore, Tamilnadu, India. \\ ${ }^{3}$ Department of Chemistry, M.Kumarasamy College of Engineering, Karur, Tamilnadu, India. \\ ${ }^{4}$ Department of Chemical Engineering, Anna University, Chennai, India.
}

http://dx.doi.org/10.13005/bbra/2930

(Received: 22 June 2021; accepted: 09 September 2021)

\begin{abstract}
The world is presently hectic in a battle against the strong and lethal COVID-19 virus, which is not only dangerous to the body but also psychologically distressing due to the growing number of patients infected and dying worldwide. This paper includes a concise overview of the possible therapies as well as the elements associated with intensive care, which have been identified with promising clinical outcomes, based on the knowledge we have gathered so far. Furthermore, as the SARS-CoV-2 virus is better understood, recent drugs focussing certain parts of the virus are being developed, and anti-SARS-CoV-2 vaccines are being researched. This timely study examines the existing condition of COVID-19 across the globe. This topic will bring to light the potential for drug development and vaccination in different parts of the world to combat the epidemic, and some of this may be of use in the future.
\end{abstract}

Keywords: COVID-19; Drugs; Epidemics; Potential therapies; SARS-CoV-2 virus; Vaccines.

The world is facing a deadly pandemic. Primarily, an unidentified etiology caused respiratory illness near Wuhan of 29 cases in china ${ }^{1}$. The Chinese Center for Disease Control and Prevention (CDC) began looking into the novel virus. They initially labeled it as pneumonia with an unclear cause. After research, they addressed this novel virus to be belonged to coronavirus (CoV) family. They termed it as COVID-19, which is nothing but the acronym for coronavirus disease 2019. Soon, this virus spread rapidly all over the world. This COVID-19 is highly contagious, and several million people have been died globally and it's still pandemic in many countries. This novel virus has been evolved over 18 countries among those 4 countries through humanhuman transmission. In the timeline of past twenty years, there were already two 2 deadly epidemics occurred across the world. They were severe acute respiratory syndrome SARS-CoV which was first found in china in the period of 2002-2003 and other one is Middle East respiratory syndrome corona virus (MERS-CoV) Saudi Arabia which occurred first in $2012^{2}$. In accordance with The International Committee on Taxonomy of Viruses (ICTV), the novel coronavirus (COVID-19) was termed as SARS-CoV-2; considering it's similarity to that of SARA-CoV outburst. The novel coronavirus has got a structure that resembles a positive single stranded RNA virus having a crown like structure 
visualized under an electron microscope and therefore termed as coronam in Latin it means crown and this is in regards with the spike (S) glycoprotein on the envelope ${ }^{3}$.

\section{Genera: 4 types}

1. Alpha coronavirus (Alpha CoV)

2. Beta Coronavirus (Beta $\mathrm{CoV}$ )

3. Delta Coronavirus (Delta $\mathrm{CoV}$ )

4. Gamma Coronavirus (Gamma CoV)

According to research, the genomic characterization of bats and rodents has the gene source of alpha CoVs and beta CoVs; avian species have the gene source of delta CoVs and gamma CoVs. Recently, seven humans CoVs has been identified and named as HCoVs which has the capacity to infect humans. Some of the human CoVs are as follows; HCoV-OC43, HCoV-HkU1, HCoV-229F, HCoV-NL63, SARS-CoV, SARS$\mathrm{CoV}-2$ and MERS-CoV. Most commonly acting human CoVs is SARS-CoV-2 which is accountable for present pandemic outbreak that belongs to beta $\mathrm{CoV}$ family.

\section{Taxonomic Hierarchy of Novel Virus}

\begin{tabular}{ll}
\hline Order & Nidovirales \\
Family & Coronaviridae family \\
Sub-family & Orthocoronavirinae family \\
\hline
\end{tabular}

\section{SARS-CoV-2 Virus}

It is a pleomorphic shape with a round or elliptic structure. The diameter ranges between 60 and 140 nanometers. This virus is sensitive to ultraviolent radiation and heat. The studies reveal that, increases in temperature of about $27^{\circ} \mathrm{C}$ and above can be activate the virulence effect of virus. Although when treated with ether, ethanol, chlorine-containing disinfectant, peroxyacetic acid, and chloroform, these viruses were inhibited. As reported by Chan et al., the new virus SARS-CoV-2 has a single-stranded RNA genome with 29891 nucleotides and 9860 amino acids encoded. For both SARS-CoV and MERS-CoV, an envelope spike (S) glycoprotein binds around the cellular receptors angiotensin converting enzyme 2 (ACE2) and dipeptidyl peptidase (DPP4). The process of this new virus is that the viral RNA genome is delivered into the cytoplasm at first, then replication of viral genome takes place, after that the genomic RNA accompanies with envelope glycoproteins and nucleocapsid protein that results in virion containing vesicles, which finally incorporate into plasma membrane and release the virus.

\section{Statistics - Occurrence of death and recovered Medication Procedure}

A novel corona virus were originated in some parts of china, which includes Wuhan,

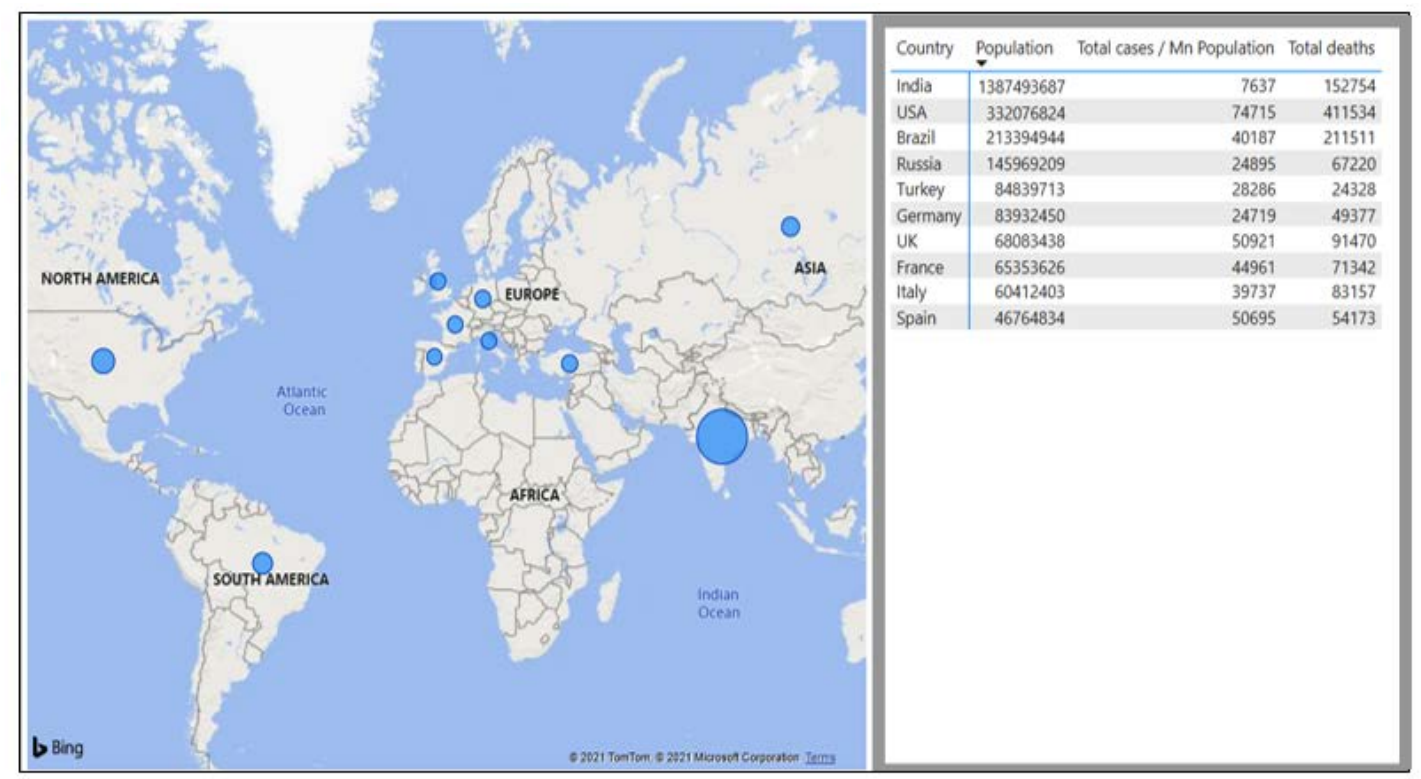

Fig. 1. World top 10 countries, overall population, overall cases, and overall deaths 
Hubei Province on December 2019..$^{4-6}$ The World Health Organization (WHO) designated this pandemic outbreak as a public health emergency of worldwide concern on January 30, 2020. ${ }^{7-9}$ As per the Chinese study, there are six strains of corona virus that are infectious to humans, each named after their appearance with a single stranded RNA genome. ${ }^{10}$ They also confirmed that, like SARS and MERS, SARS-CoV-2 is highly infectious and causes serious breathing illness and ultimately death. ${ }^{11}$ As long as this SARS-CoV-2 is highly vulnerable to humans it makes even worse with the elderly and other diseased people. ${ }^{12-14}$ The Chinese researchers employs that it's hard to introduce a new drug, which approximately takes 15 years, so to control this situation they decided to make a new drug manipulating from the existing drug in the market, just to eradicate the occurrence of disease, so as a result they followed Chinese traditional medicine. ${ }^{15}$

\section{Traditional Chinese Medicine}

The treatment approach for COVID patients is divided into two parts, according to their clinical experience: a medical observation phase and a clinical therapy phase. Confirmed cases were handled during the clinical therapy phase based on four symptoms, which were as follows:

Based on the patient's pathological conditions, different medications and treatment were used at different stages. ${ }^{17-18}$ According to research, till date 23 different Chinese medicines were approved and given to treat mild, severe and critical symptoms (Table 2$)^{19}$

As listed in the table. 3, above these are the chemical medicines which were widely used to treat mild, severe, critical COVID patients. Along with these medicines there were also some other chemical medicines were gone for clinical trials, which includes Chloroquine Phosphate, Darunavir, Emtricitabine and Denofovir Alafenamide. The Chinese also dealt with some biological medicines and techniques for the treatment of COVID 19 and were listed in the following table. 4

Human immunoglobulin and intestine micro ecological regulator are among the biological medications found on COVID-19. Chinese medicines offer a wide range of applications, particularly in the treatment of minor symptoms.3.2 Evolution of Medicine in India. As per recent research, India, having a population of over 1.36 billion people, is the second-vast nation with a significant number of COVID-19 instances; one of the numerous causes for this abrupt and uncontrollable increase was India's lack of ventilators, which totalled just 49,000 (Mumbai, 2020). Indian government initiated various preventive and precaution measures to control the pandemic. The Ministry of Health and Family

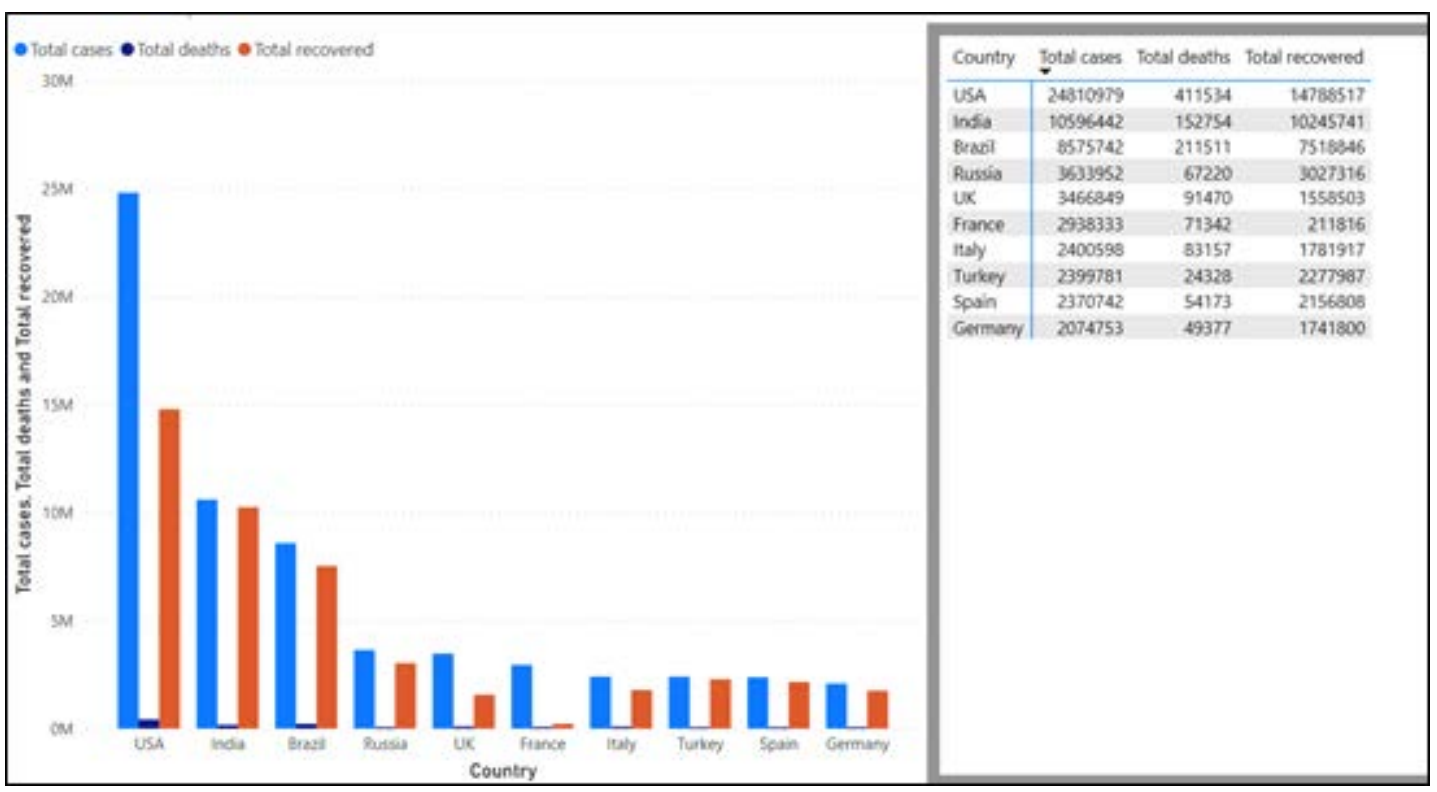

Fig. 2. World top 10 countries, total cases, total deaths and total recovered 
Welfare (MOHFW) have elevated awareness about the present epidemic and implemented a number of necessary steps to combat COVID-19. People who had travelled from China or other countries and had any of the symptoms, such as fever, trouble breathing, sore throat, cough, and dyspnea, were advised to seek medical attention at the local hospital. Seven separate airport authorities have been asked to check and monitor Indian travellers from China and other impacted nations, including those in Chennai, Kochi, Kolkata, New Delhi, Telungana, and Bangalore.

The following figure 5 clearly explains the growth of COVID-19 cases in India and its current scenario and the present active and confirmed cases.

India is popular for its conventional medicines, or AYUSH (Ayurvedic, Yoga \& Naturopathy, Unani, Siddha \& Homeopathy). One of most promising medication followed by Indians were polyherbal powder Nilavembu Kudineer, which was effectively treating dengue and chikungunya fever ${ }^{47}$. With the collaboration with WHO ICMR decided to work on useful medications to improve the immunity that fight against the corona virus. The researchers of India studied various types of drugs and the therapeutic effects to enhance the people with immunity. There was a evolution of medicines in India from the start of this outbreak.

According to researchers, the COVID-19 therapies is done under two categories which includes antiviral that averts the virus from accumulating and other one is immune modulators that helps the immune system to oppose the virus. ${ }^{48}$

Based on the category, the following are the list of COVID-19 antiviral

- Remdesivir

- Umifenovir

- Chloroquine/hydroxychloroquine

- Lopinavir/ritonavir combination

- Niclosamide

- Ribavirin

- Oseltamivir

- EIDD-2801

- Ivermectin\& Doxycycline

- Favipiravir

The following is a list of COVID-19 immune modulators on the basis of immune modulators.

- Dexamethasone

- Hydrocortisone

- Budesonide (inhaled)

- Azithromycin

- Tocilizumab

- Baricitinib

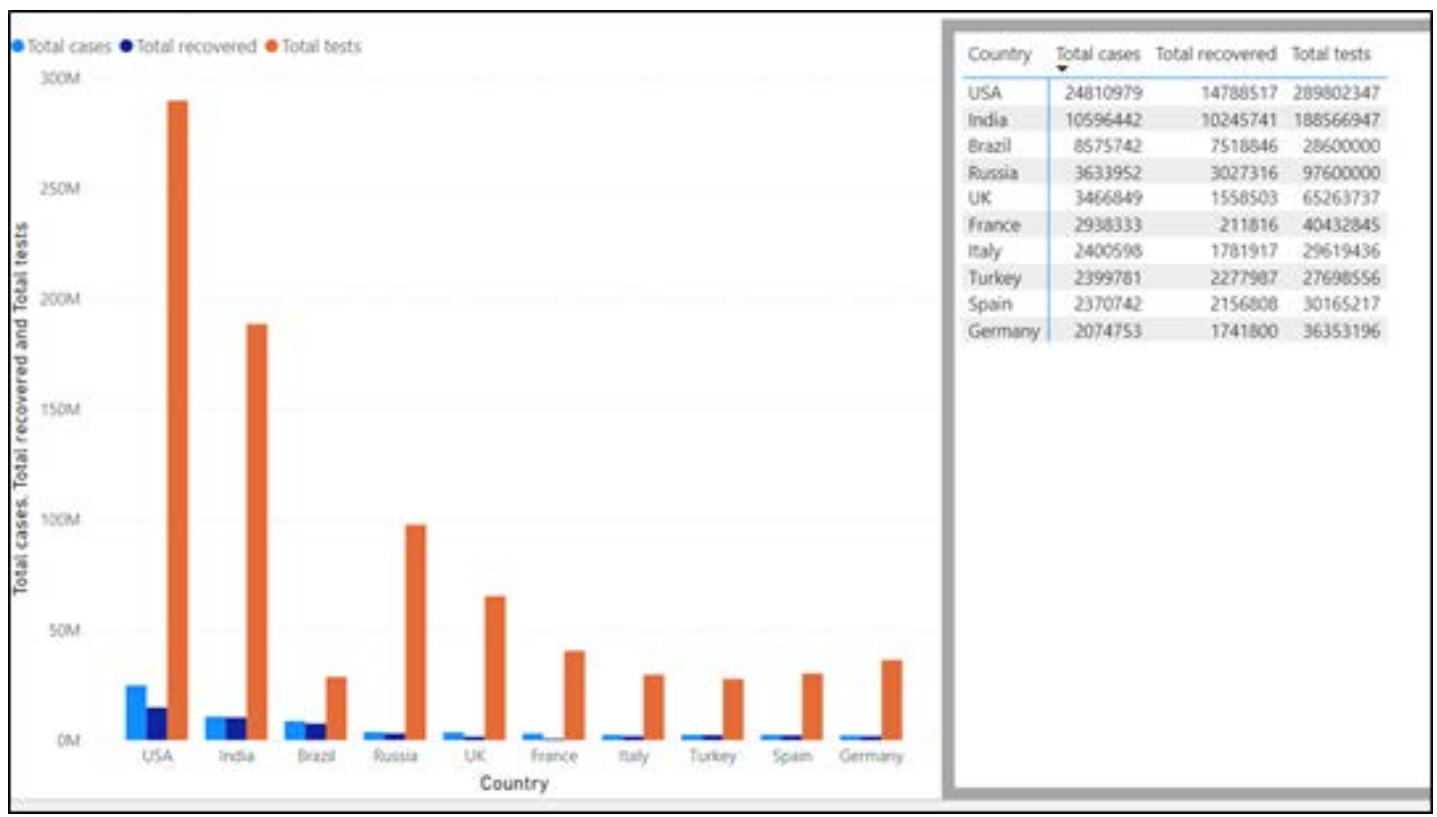

Fig. 3. World top 10 countries, total cases, total recovered, total test 
- Sarilumab

- Convalescent plasma

- Canakinumab

- Anakinra

- Ruxolitinib

- Acalabrutinib

- Interferons

- AZD7442

- Brensocatib

- Ravulizumab

- Namilumab

- Lenzilumab

- Medi3506

- Infliximab

- Adalimumab

- Otilimab

- Gemtuzumab ozogamicin

- Antiviral antibody cocktail

- Leronlimab

- LY-CoV555

- LY-CoV016

- Risankizumab

- IMU-838

There are some more drugs apart from these two categories. They are as follows.

- Colchicine

- Fluvoxamine

- Angiotensin-converting-enzyme inhibitors/ angiotensin-II receptor blockers

- Zilucoplan

- Statins

- Anticoagulants

- Omeprazole

- Clopidogrel

- Bemcentinib

- Famotidine

- Razuprotafib

- Ascorbicacid/vitamin C

- Aviptadil

- Opaganib
- Aspirin

- Tradipitant

- AZD1656

- Nitric oxide

The above are the some of the drugs, used for treating the COVID patients which were studied so far by the researchers. ${ }^{49}$ Among all these medicines, antiviral, and immune modulators, according to researchers, certain antiviral drugs and immune modulators were effectively used for treating the COVID patients that are listed in the following figures 7(a) \& (b).

\section{Remdesivir}

Remdesivir is one of the broad-spectrum antiviral medications that was first produced in 2014 to cure hepatitis C and afterwards the Ebola virus. Remdesivir has been shown to have action against SARS-CoV 2 and MERS CoV in in-vitro and animal investigations. ${ }^{50-51}$ This remdesivir is an injectable medication that is exclusively available in hospitals. It is mostly utilised for COVID-19 individuals who have been classified as moderate to severe. ${ }^{52}$ The US National Institutes of Allergies and Infectious Diseases released preliminary study findings on covid patients' recuperation growth in May 2020, indicating that recovery increased from 15 to 11 days following remdesivir treatment. The Indian Drug Controller General authorised a fiveday remdesivir regimen in June. ${ }^{53}$ The WHO issued a provisional guideline about the use of remdesivir in severe patients in November 2020, citing a lack of clear findings that remdesivir enhances therapeutic efficacy and other consequences. ${ }^{54}$ The remdesivir had very less influence on the fatality of individuals diagnosed for COVID, according to preliminary data from the solidarity study.

\section{Chloroquine / Hydroxychloroquine}

Chloroquine has a history of 70 years for treating chloroquine sensitive malaria, extraintestinal amoebiasis, systemic lupus erythematous (SLE),

Table 1. Clinical treatment period based on four manifestations ${ }^{16}$

\begin{tabular}{ll}
\hline Cases & Symptoms \\
\hline Mild & Cold-damp restraint in the lung pattern or damp-heat amassing in lung pattern \\
Moderate & Damp-toxin restraint in the lung pattern or cold-damp hindering the lung pattern \\
Severe & Epidemic toxin which chunks the lung pattern \\
Critical & Internal blockage and external discarding pattern \\
Rehabilitation & Presence of Lung and spleen shortage patterns \\
\hline
\end{tabular}


Table 2. Chinese Traditional Medicine ${ }^{20}$

\begin{tabular}{|c|c|c|}
\hline $\begin{array}{l}\text { Proprietary } \\
\text { Chinese medicines }\end{array}$ & Application stage & Indications \\
\hline $\begin{array}{l}\text { Jinhua } \\
\text { Qinggan } \\
\text { granules }\end{array}$ & $\begin{array}{l}\text { Medical assessment period } \\
\text { - clinical demonstration } 2\end{array}$ & $\begin{array}{l}\text { Fever, headache, sore body and throat, cold and } \\
\text { cough, bad wind, stifling nose, red tongue, } \\
\text { thin yellow fur }\end{array}$ \\
\hline $\begin{array}{l}\text { Huoxiangzhengqi } \\
\text { capsule } \\
\text { (pill, oral liquid) }\end{array}$ & $\begin{array}{l}\text { Medical examination period } \\
\text { - clinical demonstration } 1\end{array}$ & $\begin{array}{l}\text { Detestation to cold without sweat, headache, } \\
\text { increased body weight, limb pain, chest Diaphragm } \\
\text { full, aversion to drinking, loose stools, } \\
\text { drowning short }\end{array}$ \\
\hline $\begin{array}{l}\text { Lianhua } \\
\text { Qingwen capsules } \\
\text { (granules) }\end{array}$ & $\begin{array}{l}\text { Medicinal observation period } \\
\text { clinical manifestation } 2\end{array}$ & $\begin{array}{l}\text { Fever, chills, muscle and joint pain, stuffy nose, } \\
\text { runny nose, cough, headache, nasal congestion, } \\
\text { dry throat, sore throat, red tongue, yellow, } \\
\text { or greasy fur }\end{array}$ \\
\hline $\begin{array}{l}\text { Jingyin } \\
\text { granules }\end{array}$ & - & $\begin{array}{l}\text { Clearing heat and detoxifying, moistening } \\
\text { lung, and throat }\end{array}$ \\
\hline $\begin{array}{l}\text { ShufengJiedu } \\
\text { capsules } \\
\text { (granules) }\end{array}$ & $\begin{array}{l}\text { Medicinal observation period } \\
\text { — clinical manifestation }\end{array}$ & $\begin{array}{l}\text { Fever, bad wind, sore throat, headache, } \\
\text { stuffy nose, runny nose, cough, red tip of tongue, } \\
\text { thin white dry or yellow tongue coating, } \\
\text { floating pulse }\end{array}$ \\
\hline $\begin{array}{l}\text { Xiyanping } \\
\text { injection }\end{array}$ & $\begin{array}{l}\text { Medicinal treatment period } \\
\text { - severe }\end{array}$ & $\begin{array}{l}\text { High fever and polydipsia, dyspnea and anhelation, } \\
\text { delirium, obscured vision, impaired voice, acne, } \\
\text { or hematemesis and epistaxis, or convulsion of } \\
\text { the limbs. Tongue with insufficient or no fur, } \\
\text { deep and count pulse, rapid pulse }\end{array}$ \\
\hline $\begin{array}{l}\text { Xuebijing } \\
\text { injection }\end{array}$ & $\begin{array}{l}\text { Clinical treatment period } \\
\text { - severe and critical }\end{array}$ & $\begin{array}{l}\text { High fever and polydipsia, dyspnea and anhelation, } \\
\text { delirium, obscured vision, acne, or hematemesis } \\
\text { and epistaxis, or convulsion of the limbs. Tongue } \\
\text { with scanty or no fur, deep and count pulse, } \\
\text { rapid pulse }\end{array}$ \\
\hline $\begin{array}{l}\text { Reduning } \\
\text { injection }\end{array}$ & $\begin{array}{l}\text { Clinical treatment period } \\
\text { - severe and critical }\end{array}$ & $\begin{array}{l}\text { High fever and polydipsia, dyspnea and anhelation, } \\
\text { delirium, obscured vision, acne, or hematemesis } \\
\text { and epistaxis, or convulsion of the limbs. Tongue } \\
\text { with scanty or no fur, deep and count pulse, } \\
\text { rapid pulse }\end{array}$ \\
\hline $\begin{array}{l}\text { Shenfu } \\
\text { injection }\end{array}$ & $\begin{array}{l}\text { Clinical treatment period } \\
\text { — critical }\end{array}$ & $\begin{array}{l}\text { Dyspnea, asthma requires assisted ventilation, } \\
\text { dizziness, irritability, cold sweaty limbs, } \\
\text { purple tongue, thick or dry fur, large floating, } \\
\text { and rootless pulse. }\end{array}$ \\
\hline $\begin{array}{l}\text { Shengmai } \\
\text { injection }\end{array}$ & $\begin{array}{l}\text { Clinical treatment period } \\
\text { - critical }\end{array}$ & $\begin{array}{l}\text { Dyspnoea, asthma requires assisted ventilation, } \\
\text { dizziness, irritability, cold sweaty limbs, purple } \\
\text { tongue, thick or dry fur, large floating, and } \\
\text { rootless pulse. }\end{array}$ \\
\hline Angongniuhaung-wan & $\begin{array}{l}\text { Clinical treatment period } \\
\text { — clinical period } 2\end{array}$ & $\begin{array}{l}\text { Throwing away heat, detoxifying, calming and } \\
\text { resuscitating, fever, pathogen getting into } \\
\text { pericardium, febrile convulsion, delirium, crimson } \\
\text { tongue, very high pulse number; apoplexy coma } \\
\text { and encephalitis, meningitis, toxic encephalopathy, } \\
\text { cerebral haemorrhage, septicaemia }\end{array}$ \\
\hline $\begin{array}{l}\text { Xingnaojing } \\
\text { injection }\end{array}$ & $\begin{array}{l}\text { Clinical treatment period } \\
\text { - severe and critical }\end{array}$ & $\begin{array}{l}\text { Symptoms include severe fever and polydipsia, } \\
\text { dyspnea and anhelation, delirium, impaired vision, } \\
\text { rash, hematemesis, epistaxis, and limb convulsions. } \\
\text { Tongue with hardly any fur, a profound and slow } \\
\text { pulse, or a fast and massive pulse }\end{array}$ \\
\hline
\end{tabular}


and rheumatoid arthritis. ${ }^{55-56}$ Even though, the Chloroquine has some essentials benefits it has adverse side effects that includes at higher doses of chloroquine ophthalmologic reactions namely retinal toxicity, reducedvisual acuity, visual loss, and diplopia, due to the selectivebinding of CQ to retinal melanin. ${ }^{57}$ Hydroxychloroquine is a derivative of Chloroquine. Hydroxychloroquine is an antimalarial drug, has a invitro activity against various viruses including SARS-CoV-2. ${ }^{58}$ According to researchers, they reveal that the hydroxychloroquine has an increased toxic behaviour which leads to cardiovascular problems. Various investigations have revealed that postexposure treatment with hydroxychloroquine did not demonstrate any benefit against SARS-CoV-2 infection or symptomatic COVID-19 infection in people having good health. ${ }^{59}$ Also before the

Table 3. Chemical Medicine and Biological Medicine Undertaken to treat Chinese patients ${ }^{21}$

\begin{tabular}{|c|c|c|c|}
\hline Medicine & Chemical/Biological & Mechanism of Action & Indications \\
\hline $\begin{array}{l}\text { Lopinavir/ } \\
\text { Ritonavir }\end{array}$ & $\begin{array}{l}\text { Chemical } \\
\text { (antiviral drug) }\end{array}$ & $\begin{array}{l}\text { Invitro studies exploits that } \\
\text { this medicine inhibits the } \\
\text { replication of MERS-CoV } \\
\text { \& SARS-CoV. }\end{array}$ & $\begin{array}{l}\text { Once a day }(800 \mathrm{mg} / 200 \mathrm{mg}) \text { is the } \\
\text { recommended oral dosage. boost } \\
\text { treatment adherence, lessen } \\
\text { adverse responses, control the } \\
\text { dissemination of the virus } \\
\text { through urine and faeces, and } \\
\text { halt the epidemic's spread }{ }^{22}\end{array}$ \\
\hline Ribavirin & $\begin{array}{l}\text { Chemical } \\
\text { (nucleoside } \\
\text { antiviral drug) }\end{array}$ & $\begin{array}{l}\text { Invitro studies show that it } \\
\text { lessens viral infection and } \\
\text { eminently used for the } \\
\text { treatment of MERS \& SARS. } \\
\text { It also inhibits both DNA\& } \\
\text { RNA viruses. }\end{array}$ & $\begin{array}{l}\text { It can regulate and improve a } \\
\text { patient's condition when given } \\
\text { in combination with -interferon } \\
\text { or lopinavir, } 500 \mathrm{mg} / \text { time for } \\
\text { adults with } 2 \text { to } 3 \text { intravenous } \\
\text { injections per day, however } \\
\text { the therapeutic procedure } \\
\text { should be limited to } 10 \text { days. }{ }^{23}\end{array}$ \\
\hline Arbidol & $\begin{array}{l}\text { Chemical } \\
\text { (non-nucleoside } \\
\text { antiviral drug) }\end{array}$ & $\begin{array}{l}\text { When compared to a } \\
\text { drug-free control group, } \\
10-30 \text { mol of arbidol } \\
\text { substantially inhibited } \\
\text { SARS-CoV-2 growth by } \\
60 \text { times and dramatically } \\
\text { inhibited viral pathogenic } \\
\text { effects in vitro }{ }^{24}\end{array}$ & $\begin{array}{l}\text { It prevents the viral lipid } \\
\text { membrane from fusing with } \\
\text { the host cell, preventing } \\
\text { virus multiplication. }{ }^{25-26}\end{array}$ \\
\hline Remdesivir & $\begin{array}{l}\text { Chemical } \\
\text { nucleoside } \\
\text { drug }\end{array}$ & $\begin{array}{l}\text { In vitro and in animal models, } \\
\text { Remdesivir has showed good } \\
\text { anti-MERS-CoV and } \\
\text { anti-SARS-CoV activity. }{ }^{27}\end{array}$ & $\begin{array}{l}\text { According to research, remdesivir } \\
\text { showed the highest inhibitory } \\
\text { effect on COVID- } 19 \text { in vitro } \\
(\text { EC } 50=0.77 \mathrm{~mol} / \mathrm{L}) \text { of the } \\
\text { six antiviral medications studied. }{ }^{28}\end{array}$ \\
\hline Favipiravir & $\begin{array}{l}\text { Chemical / } \\
\text { nucleoside } \\
\text { antiviral drug }{ }^{29}\end{array}$ & $\begin{array}{l}\text { The medication was first } \\
\text { used to treat influenza }{ }^{30} \text {, } \\
\text { but it now has inhibitory } \\
\text { action against nearly all RNA } \\
\text { viruses, including West Nile } \\
\text { virus, yellow fever virus, } \\
\text { enterovirus, and Ebola virus. } .^{31-32}\end{array}$ & $\begin{array}{l}\text { Favipiravir has emerged as a } \\
\text { viable treatment for COVID-19 } \\
\text { patients }^{33}, \text { Favipiravir } \\
(\text { EC50 }=61.88 \mathrm{~mol} / \mathrm{L}) \text { is } \\
\text { effective against } \\
\text { SARS-CoV-2 }{ }^{34}\end{array}$ \\
\hline $\begin{array}{l}\text { Hydroxy- } \\
\text { chloroquine }\end{array}$ & $\begin{array}{l}\text { Chemical / } \\
\text { antimalarial drug }\end{array}$ & $\begin{array}{l}\text { In vitro investigations have } \\
\text { shown that hydroxychloroquine } \\
\text { has a therapeutic impact against } \\
\text { the Ebola and dengue viruses. }\end{array}$ & $\begin{array}{l}\text { It was recently discovered that } \\
\text { hydroxychloroquine medication } \\
\text { helped some COVID-19 } \\
\text { patients. }\end{array}$ \\
\hline
\end{tabular}


treatment with hydroxychloroquine, administered once or twice a week, had no effect on laboratoryverified COVID-19 patients or COVID-19 disease amongst healthcare professionals. ${ }^{60}$ Patients having mild to moderate COVID-19 were hospitalised and administered a combination of hydroxychloroquine and azithromycin did not demonstrate any improvement after 15 days of observation when compared to standard treatment. ${ }^{61}$ Even when this hydroxychloroquine given to severity categorized covid-19 patients, it did not substantially reduce or control the symptoms. ${ }^{62}$ Thus not enough data were available to recommend hydroxychloroquine as a drug to treat COVID-19 patients. ${ }^{63}$

Favipiravir

Favipiravir is a broad-spectrum type antiviral medication that stops viruses from replicating. It's also an anti-influenza medication. Fujifilm Toyama Chemical Ltd of Japan was the first to market with it, followed by Glenmark Pharmaceutical and Strides Pharma. COVID-19 individuals in the moderate to severe group are treated with it. ${ }^{64}$ The Glenmark underwent Phase III clinical studies to assess favipiravir's efficacy and safety in COVID-19 patients. ${ }^{65}$ Favipiravir is an antiviral medication that has been approved by India's Drug Controller General. For the treatment of moderate infections, it received an Emergency Use Authorization. ${ }^{66}$

Tocilizumab

Cipla is the brand name for tocilizumab, which is produced by Roche Pharma.

Table 4. Biological medicines and techniques for the treatment of COVID patients ${ }^{37}$

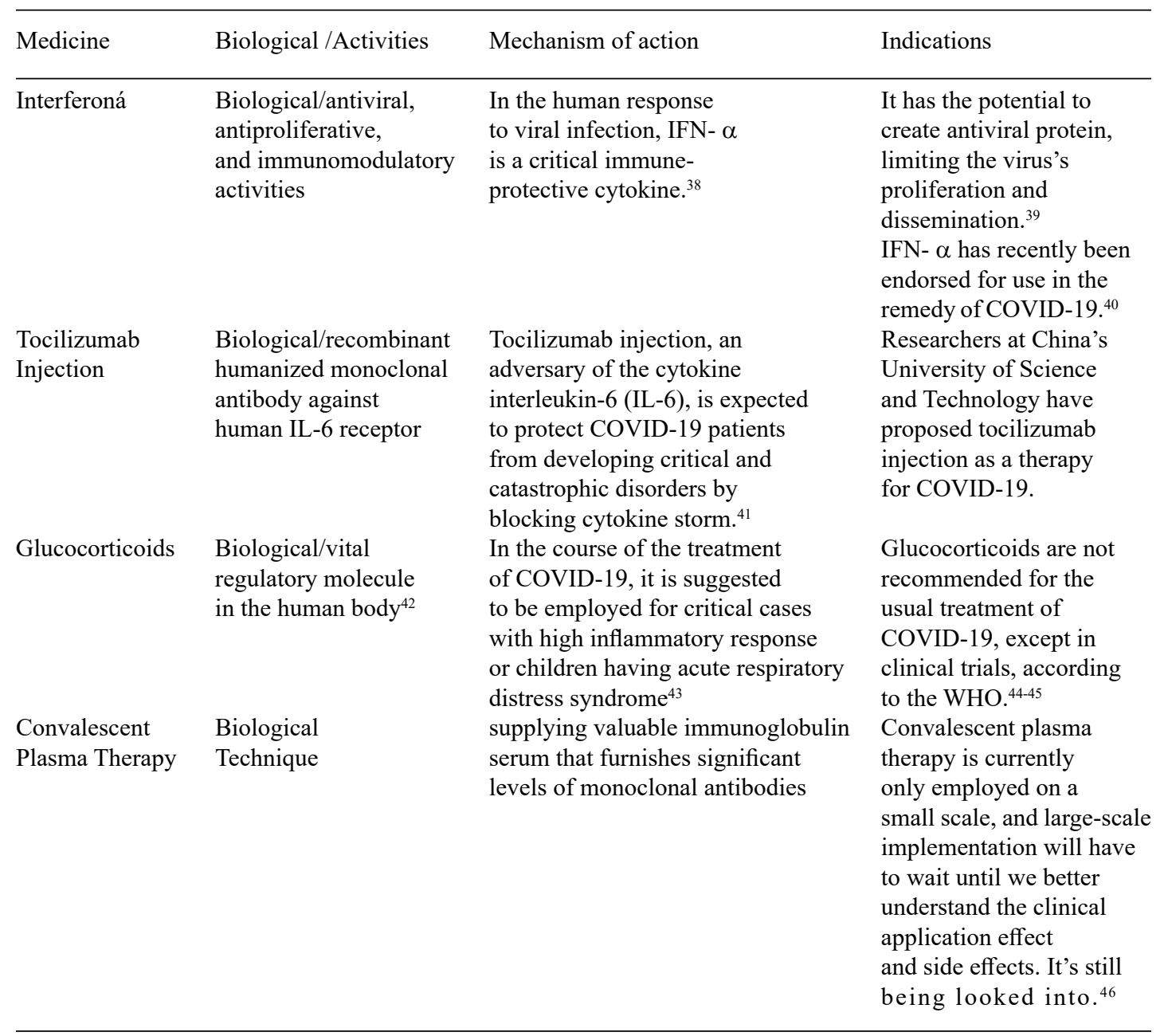


While Actemra is the brand name in India. The antineoplastic tocilizumab is primarily used to cure rheumatoid arthritis. ${ }^{67}$ It's a monoclonal antibody that blocks interleukin-6 (Il-6), a critical component of the immune reaction to SARSCoV-2. Tocilizumab, an intravenous medication licenced as an off-label therapy for moderate to severe COVID-19 patients, will likewise be available only in hospitals. ${ }^{68}$ There were no excellently done studies showing the effectiveness and safety of tocilizumab towards COVID-19, as per the expert. ${ }^{69}$ By day 14, tocilizumab can minimise the requirement for mechanical breathing or mortality in patients, but it can't regulate morality by day $28 .{ }^{70}$ In India, randomised control trials have commenced. ${ }^{71}$

\section{Ritonavir + Lopinavir}

This antiviral combination of ritonavir and lopinavir is primarily used to treat HIV patients. It's an HIV type I aspartate inhibitor that's used in combination with several other antiretroviral medicine for treating HIV infection. In vitro, lopinavir inhibits SARS-CoV, but ritonavir, when combined with lopinavir, increases the half-life. Based on the current emerging results from the recovery trials, ritonavir + lopinavir had no positive effect on 28-day fatality in COVID 19 patients as compared to conventional treatment. ${ }^{72}$ When triple antiviral therapy was given among the patients that includes (IFN) beta-Ib, ritonavir + lopinavir and ribavirin along with usual care, it was safe and it reduces the duration of viral shedding than ritonavir + lopinavir alone especially in mild to moderate COVID-19 patients. ${ }^{73}$ According to certain trials, when ritonavir + lopinavir was administered within 12 days of the beginning of symptoms, there was modest updated accordingly, but no diminution in RNA viral injection, identification of viral longevity, or time from randomization to death. As a result, ritonavir + lopinavir has been discontinued in 13 individuals because to negative side effects ${ }^{74}$ Doxycycline + Ivermectin

Ivermectin was an anti-parasitic agent with antiviral activity. In vitro, it has modest inhibitory

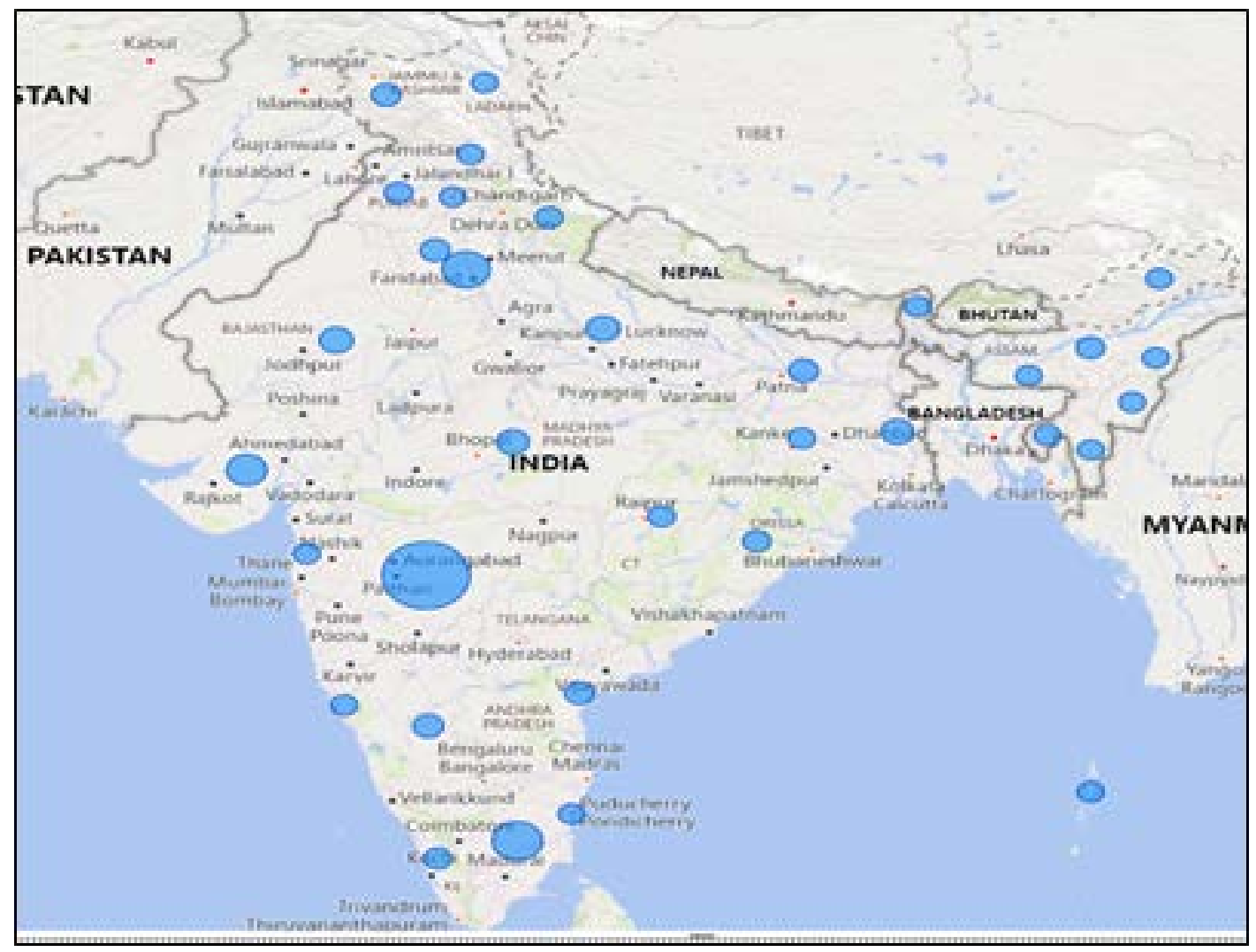

Fig. 4. India - Total cases, total deaths, and confirmed cases, with cured cases within states and union territories 
effect against the SARS-CoV-2 virus. Doxycycline is an antibiotic that can be employed to treat bacterial infections of the urinary system, eyes, and lungs. The combination of both Doxycycline + ivermectin has shown some improvement against COVID-19 patients with acute symptoms. ${ }^{75}$ but the clinical trials are still under progress to reveal about the safety and efficacy of the drug. ${ }^{76}$

\section{Dexamethasone}

Dexamethasone is a kind of steroid that reduces inflammation by imitating the body's anti-inflammatory hormones and treating allergic diseases. This is appropriate for individuals who have already been admitted to the hospital and are getting oxygen or mechanical ventilator. This is the first medication to show an increase in COVID-19 survival rates. ${ }^{77}$ When dexamethasone is given endovenously along with conventional therapy, it is more effective than normal care alone. For 28 days, it demonstrated a substantial growth in the number of days alive and without respiratory support. ${ }^{78}$ The recovery trial results show that this dexamethasone has reduced $35 \%$ deaths in ventilated patients and $20 \%$ patients' who received oxygen. The patients who don't have oxygen or respiratory support have no idea how it is effective, it's under research. ${ }^{79}$

\section{Convalescent Plasma}

The convalescent plasma is predominanatly for severe patients who are having scanty oxygen levels, and those who struggle from cytokine storm.Patients who have healed from extreme COVID-19 give plasma, which is subsequently injected into other critically ill patients to help them recover ${ }^{80}$ There are a few indications that show convalescent plasma may provide advantages in COVID-19 patients, however further randomized clinical trials are needed..$^{81}$ COVID-19 development was slowed when moderate patients and aged persons received high-titre convalescent plasma towards SARSCov-2. ${ }^{82}$ There was no notable change in clinical outcomes, death, or hospital discharge time in individuals treated with convalescent plasma after 28 days. ${ }^{83}$ As a result, India's medical progression is achieved.

Drugs Developed and Treated In Europe and America

According to treatment carried out in

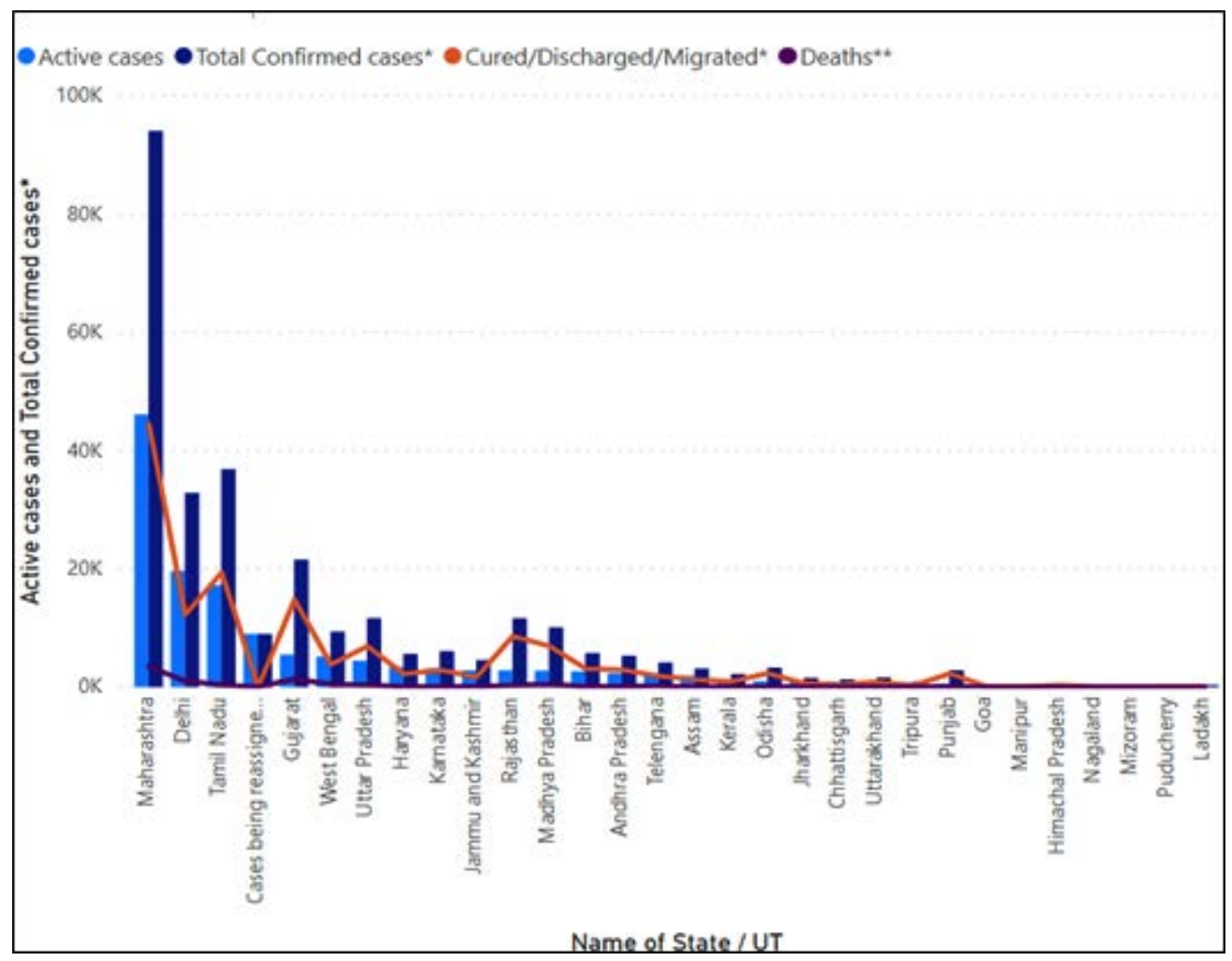

Fig.5. Active cases and confirmed cases along with cured/deaths of India and their union territories 
European countries and USA, there were 22 corona virus drugs which were given to the patients on the clinical trial basis. While some are showing a little improvement, most of the drugs are under research. The following fig. 8, categorize the list of drugs based on their improvement

The drug approved by FDA and evidence in cells, animals and humans is Remdesivir. Among 13 tentative or mixed evidence drugs, Favipiravir is one among them and it is evidence in animals, cells, and humans. Some small studies suggested that favipiravir block is the virus replication to its genetic material. Other tentative or mixed evidence drugs are Molnupiravir which can be observed in cells, animals and humans, recombinant ACE-2 which is evidence in cells, Ivermectin attestation in cells and humans and Oleandrin evidence in cells. Molnupiravir, commonly known as MK4482 or EIDD-2801, is a flu treatment drug. Early investigations in cells and animals suggest that molnupiravir is effective it against coronavirus. However, the outcomes of the clinical trials have yet to be shown. The coronavirus must first enter the cells in order to enter them. This is done by hooking on to a human protein known as ACE-2.Therefore, the scientist created recombinant ACE-2 cells, it shows promising outcomes in cells, yet to evaluate in human and animals. Ivermectin is used to treat river blindness and parasitic worms. Scientists are currently investigating if it can be used to treat viral infections. Lopivir and ritonavir, as well as hydroxychloroquine and chloroquine, were found to be ineffective in both cells and people.FDA approved this lopinavir and ritonavir combination immediately since it stops the replication and culturing of coronavirus. But it could not reveal if the patients need to be hospitalized and prevent them from new coronavirus. Trump promoted hydroxyl chloroquine will be the game changer. But FDA temporarily permitted the use of this drug, since the results from the patients were not satisfied. The above discussed drugs have the characteristic feature of blocking the virus. The immune system is the other important area to consider. These medicines elicit a powerful inflammatory reaction in order to combat the infection. Convalescent plasma is an experimental or mixed-evidence medication that has been authorised for use as an emergency treatment in cells and humans. Monoclonal antibodies are the next medication on

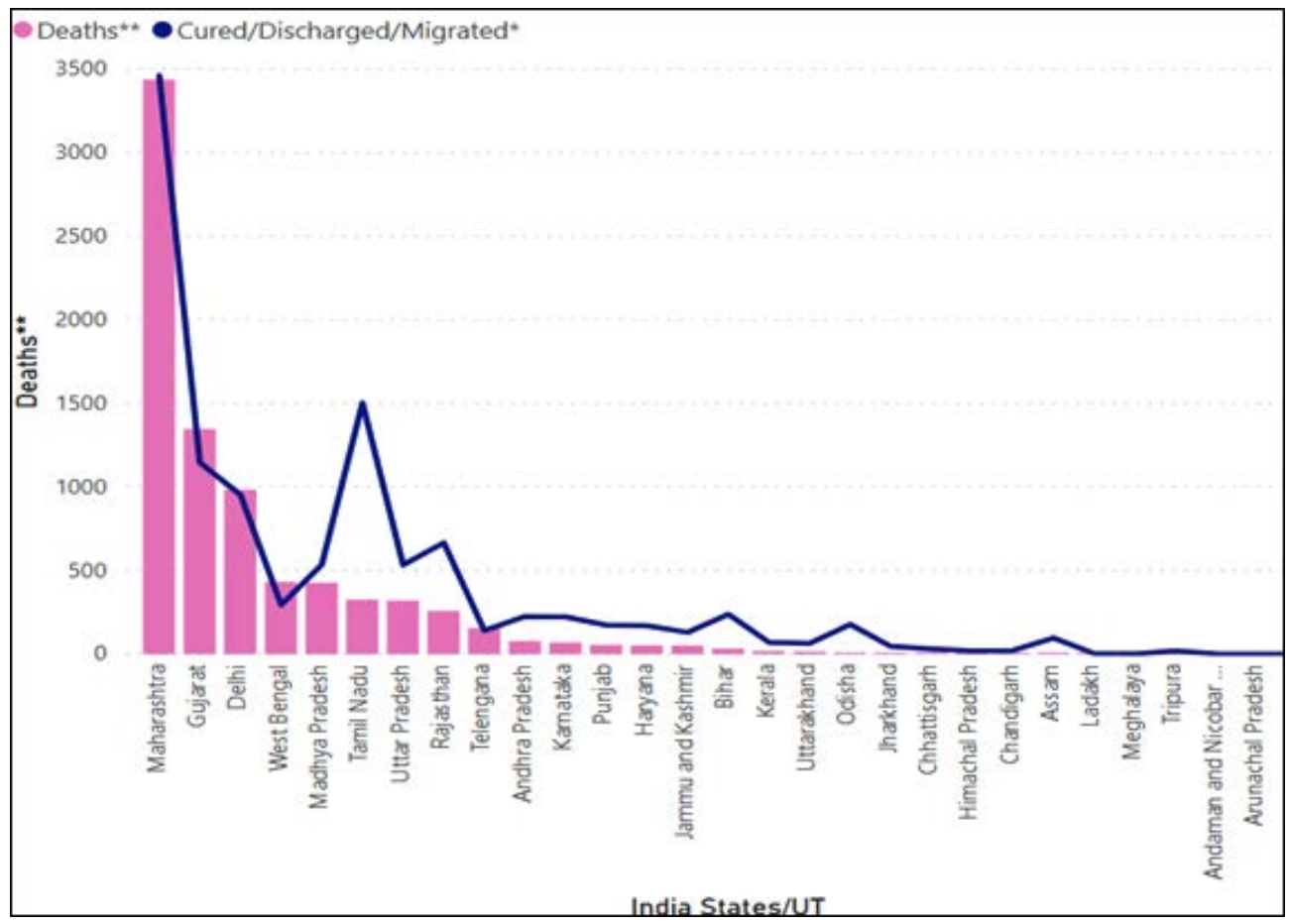

Fig. 6. Cured cases and No. of deaths in the states and union territories of India 
the list, which is likewise a preliminary or mixed evidence drug for both animals and people. It is also approved or emergency use. Another tentative or mixed evidence drug is interferons. It evidences in animals and humans. Another category is putting out friendly fire, i.e., the immune system overreacts to the virus. In this category the most promising evidence drugs in humans is dexamethasone. Trump said on October 4, 2020, that he was being medicated with dexamethasone, monoclonal antibodies, and remdesivir. In humans, cytokine inhibitors are a questionable or mixed-evidence medication. Another three tentative or mixed evidence drugs used for humans were blood filtration system, stem cells and Colchicine. These are the drugs widely used by European and American countries.

COVID-19 Vaccines across the World Initially a vaccine development requires a minimum of 36 months to enter the market after several clinical trials and testing. In this 2020, scientist was forced to design a vaccine for this new dreadful virus. There were totally 67 vaccines undergone clinical trials on humans, 20 vaccines reached testing phase which is the final stage. The following fig. 9 clearly gives the data of vaccines count and their stages.

\section{DISCUSSION}

As per Chinese scientists, traditional Chinese medicine was used to treat over 93 percent of the COVID cases in the country, which comprises a variety of therapies ranging from herbal products to acupuncture. Besides all the other Chinese traditional medicines, Lianhua Qingwen, which contains 13 herbs such as Rhodiola rose and Forsythia suspense, and Jinhua

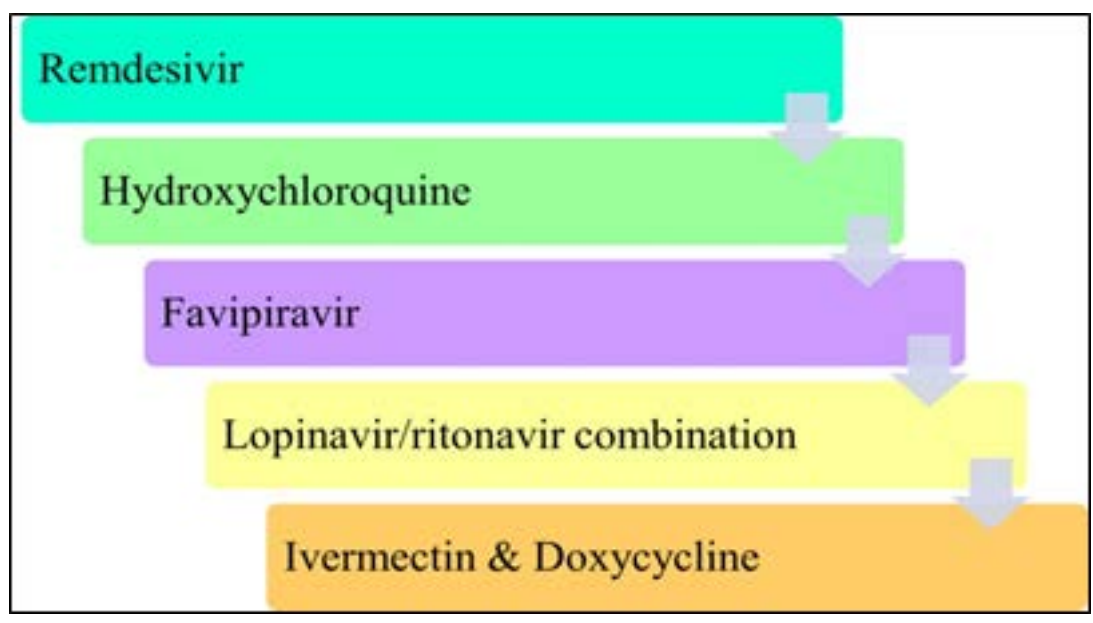

Fig. 7a. Most effectively used antiviral drugs to treat COVID-19

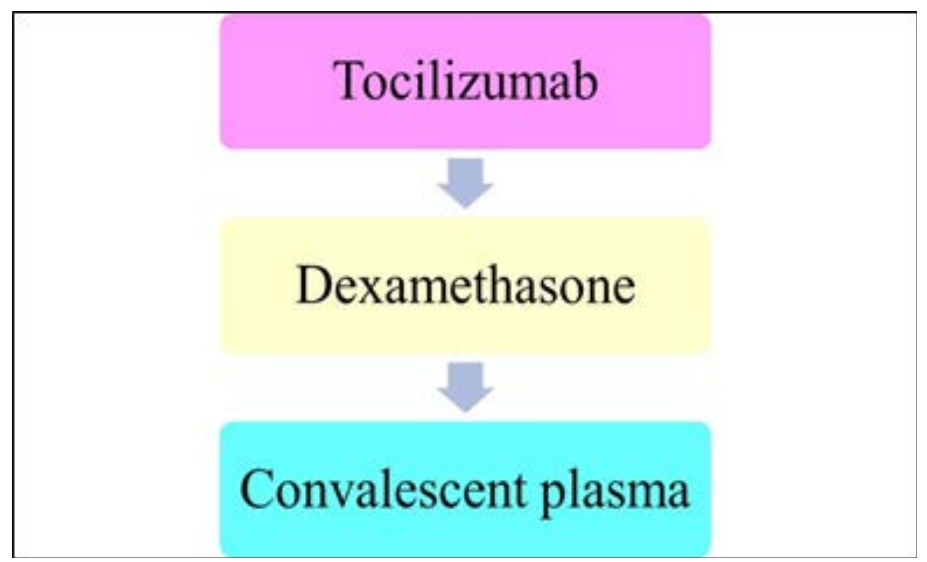

Fig. 7b. Most effectively used immune Modulators to treat coronavirus 


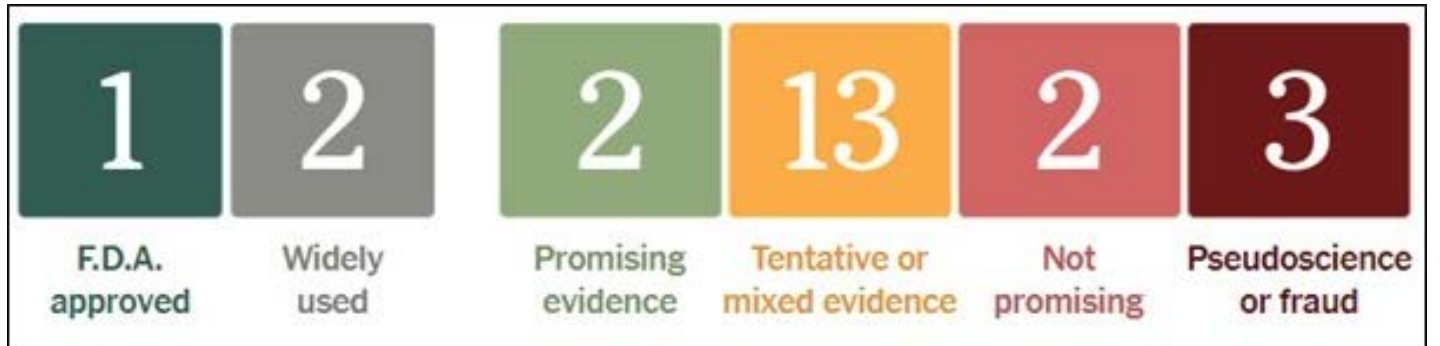

Fig. 8. List of drugs categorized among the following sectors ${ }^{84}$

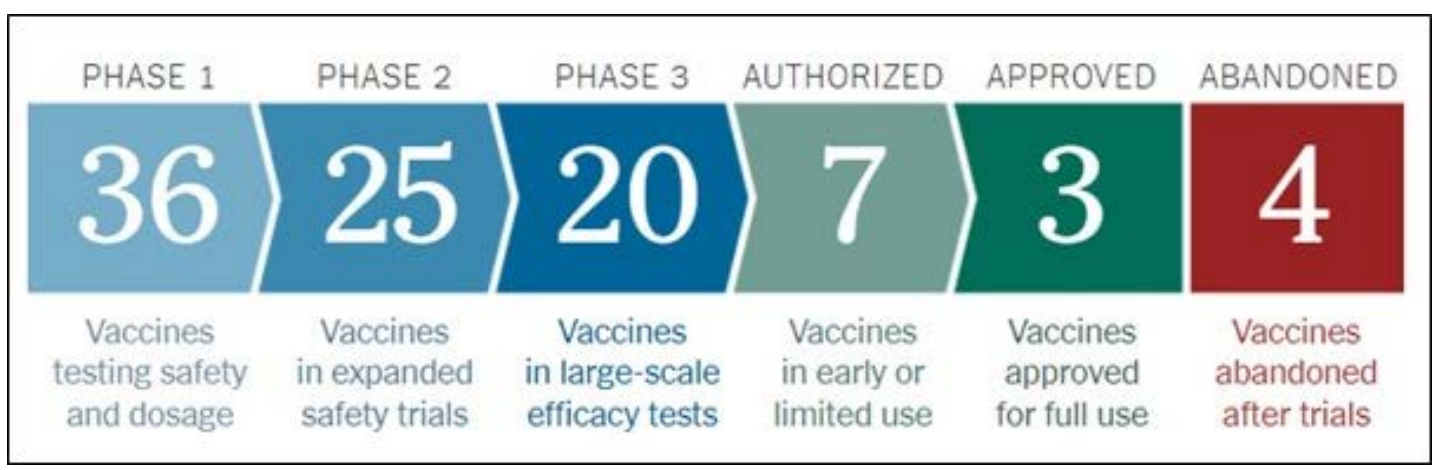

Fig. 9. Vaccines with their counts and stages of development ${ }^{85}$

Table 5. Leading Vaccines around the world, which is currently approved and in use ${ }^{\mathbf{8 6}}$

\begin{tabular}{|c|c|c|c|c|c|c|c|c|}
\hline \multicolumn{9}{|c|}{ L.A.ADING VACCTNES (APPROFED/AUTHORIZED YACCTNES) } \\
\hline Yascine Name & Developer & Work Mechanism & Phase & Status & Efficacy & Dose & Type & Storage \\
\hline $\begin{array}{c}\text { Cominaty } \\
\text { (BNr162b2) }\end{array}$ & $\begin{array}{l}\text { Pfizes- } \\
\text { BioNTedt }\end{array}$ & aRNA & $\begin{array}{c}283 \\
\text { (combsined } \\
\text { phase) }\end{array}$ & $\begin{array}{l}\text { Approved in Bahrain, Sandi Arahu, } \\
\text { Switzetland. Fmergency use in U.S, } \\
\text { E.U, odure ceualries. }\end{array}$ & $95 \%$ & $\begin{array}{c}2 \text { doses } 3 \text { week } \\
\text { apurt }\end{array}$ & $\begin{array}{l}\text { Muscle } \\
\text { Ljectiva }\end{array}$ & Ġoxder $(-70=\mathrm{C})$ \\
\hline mRNA 1273 & Moderna & mRNA & 3 Phase & $\begin{array}{l}\text { Aprovord in Switzerland.Earergency } \\
\text { use a US, U.K, E. U, others }\end{array}$ & $94.50 \%$ & $\begin{array}{c}2 \text { doses, } 4 \text { works } \\
\text { apait }\end{array}$ & $\begin{array}{l}\text { Muscle } \\
\text { Lajection }\end{array}$ & $\begin{array}{l}30 \text { days nff. } \\
\text { 6marths: } \\
20^{\circ} \mathrm{Cj}\end{array}$ \\
\hline $\begin{array}{c}\text { Sputnik } \\
\text { V(Gim-Covid- } \\
\text { Vac) }\end{array}$ & Gamsleja & Ad26, AdS & 3 phase & $\begin{array}{c}\text { E.arly use in Russis. Emergency use } \\
\text { in other countries. }\end{array}$ & $91.60 \%$ & $\begin{array}{c}2 \text { doses, } 3 \text { reneks } \\
\text { apart }\end{array}$ & $\begin{array}{l}\text { Wuscle } \\
\text { Ejjection }\end{array}$ & freezes \\
\hline $\begin{array}{c}\text { AZDi222 } \\
\text { (Cevistield in } \\
\text { India) }\end{array}$ & $\begin{array}{c}\text { Oxfori- } \\
\text { AstraZeasca }\end{array}$ & ChadoxI & $\begin{array}{c}2 \& 3 \\
\text { (coatbined } \\
\text { phass) }\end{array}$ & $\begin{array}{c}\text { Esurenency use in U.K, E.U., cther } \\
\text { coustries. }\end{array}$ & $\begin{array}{l}\text { 32.4\%s for dses } \\
\text { sepuated by } 12 \\
\text { waeks }\end{array}$ & $2 \mathrm{dcs} a$ & $\begin{array}{l}\text { Muscle } \\
\text { Ljectiva }\end{array}$ & $\begin{array}{c}\text { stable in rofe. } 6 \\
\text { months }\end{array}$ \\
\hline $\begin{array}{c}\text { Ceavidecia } \\
\text { (Ads-aCoV) }\end{array}$ & Carsino & Ads & 3 Phase & Limited isa in Chias & vaknokn & siagle dose & $\begin{array}{l}\text { Muscle } \\
\text { Lajection }\end{array}$ & Refrigersted \\
\hline Epivascaroos & Vector trsitute & Protein & 3 Phase & Early use in Russia. & takbows & $\begin{array}{c}2 \text { doses, } 3 \text { waeks } \\
\text { apart }\end{array}$ & $\begin{array}{l}\text { Uisscle } \\
\text { bjection }\end{array}$ & $\begin{array}{c}\text { stable in refe? } 2 \\
\text { years }\end{array}$ \\
\hline BВBВ-Coti & Sincpharm & Iractisated & 3 Phase & $\begin{array}{l}\text { Agproved in Chno, UA.E, } \\
\text { Batrain Emengercy use in Egspt, } \\
\text { ocher coutries. }\end{array}$ & $7934 \%$ & $\begin{array}{c}2 \text { doses, } 3 \text { wetks } \\
\text { apurt }\end{array}$ & $\begin{array}{l}\text { Muscle } \\
\text { Ljection }\end{array}$ & \\
\hline CoronaVac & Sinorect & Iractivated & 3 Phase & $\begin{array}{c}\text { Emergency use in Chins, Brszil, } \\
\text { otters }\end{array}$ & $50.80 \%$ & $\begin{array}{c}2 \text { doses, } 2 \text { weeks } \\
\text { apart }\end{array}$ & $\begin{array}{l}\text { Muscle } \\
\text { bijectiva }\end{array}$ & Refrigersted \\
\hline$\frac{\text { Covgxin }}{\text { (BBV152A, } \mathrm{B}}$ & Bharat Biatech & Iracticated & 3 Phase & Exergency use in India & Unknowr & $\begin{array}{c}2 \text { doses, } 4 \text { wetks } \\
\text { apart }\end{array}$ & & $\begin{array}{l}\text { Atlest s week } \\
\text { ut rovm teup. }\end{array}$ \\
\hline
\end{tabular}


Qinggan, which progressed during the time of 2009 H1N1 upsurge and contains 12 ingredients such as honeysuckle, liquorice and mint, are two of the most well-known medicines. ${ }^{87}$ But according to US national institute of Health and UK based researcher, they manifest that the overall effectiveness of Chinese traditional medicine is not conclusive and therefore it is dangerous, and its use is unjustified. China's National Institute for Food and Drug Control last year discovered fatal toxins in certain Chinese traditional medicine sample. ${ }^{88}$ The Chinese government and traditional medicine therapist also added that, these medicines have thousand years of history, with some significant side effects which I need to studied further and using advance research its need to be eradicated. ${ }^{89}$ The Drug Controller General of India (DCGI) have approved several repurposed drugs for treating the disease, especially on emergency purpose. But according to scientist, it is unclear; in what way the drugs have been approved and used in the market. The first drug to be approved in India was itolizumab which is mainly used to treat autoimmune disease psoriasis which was approved by Cuba to use for critical patients. The DCGI has approved emergency use of three drugs to treat COVID-19. The influenza drug favipiravir which approved for mild to moderate cases. Second, remdesivir a broad-spectrum antiviral drug and itolizumab to treat moderate to severe acute respiratory distress on people who is suffering from COVID-19. Emergency approvals were permitted based on preliminary evidence of the drugs. But scientists clearly explain that there was only limited evidence been collected stating that favipiravir and itolizumab can treat COVID-19 successfully. India is not alone involved in these fast-tracking CVOID 19 medications. Convalescent plasma treatment, hydroxychloroquine, and remdesivir have all been granted emergency necessity authorizations by the US Food and Drug Administration (FDA). ${ }^{90}$ The FDA in May 2020 issued an emergency authorization for remdesivir for the severe and critical patients who need oxygen supply. The FDA authorised the medication in August 2020, based on a study from one trial in which individuals with less

\begin{tabular}{|ll|}
\hline Feb. 3 & Vaxart stock plunges after a reported low antibody response. \\
Feb. 3 & Mexico authorizes Russia's Sputnik V vaccine. \\
Feb. 2 & Russia's Sputnik V vaccine has an efficacy of $91.6 \%$. \\
Jan. 30 & Hungary is the first E.U. country to authorize Sinopharm's vaccine. \\
Jan. 29 & The E.U. authorizes the Oxford-AstraZeneca vaccine. \\
Jan. 29 & Johnson \& Johnson reports lower efficacy data in South Africa. \\
Jan. 28 & Novavax reports lower efficacy data in South Africa. \\
Jan. 28 & South Korea's EuBiologics launches a Phase 1/2 trial. \\
Jan. 28 & Canada's Providence Therapeutics enters Phase 1. \\
Jan. 28 & Imperial College London abandons its Phase $1 / 2$ RNA vaccine. \\
Jan. 25 & Merck abandons two vaccines being developed with Themis and IAVI. \\
Jan. 21 & Gamaleya begins testing a single-dose version called "Sputnik Light." \\
Jan. 21 & Turkey's Erciyes University moves to Phase 2. \\
\hline
\end{tabular}

Fig. 10. New addition and recent updates of vaccines ${ }^{92}$ 
severe covid-19 reacted moderately to a five-day surgical procedure with remdesivir. According to the scientist, the FDA approved the drug without robust evidence. Later, October-21 when the president Trump was treated with remdesivir on a 5-day course basis. On the day of October 22, FDA immediately approved the remdesivirfor the patients of 12 years and older. But scientist reveals that there is no statistical evidence for the efficiency of remdesivir. On November 2020, WHO halted the use of remdesivir, as they do not have strong significant evidence against mortality. Favipiravir though played a crucial role in many countries that include Japan, Kenya, Russia, Saudi Arabia and Thailand, there were no large randomized clinical trial conducted, so this favipiravir drug is still under research. FDA immediately created awareness against this ivermectin, to treat COVID-19. Since this animal drug can cause adverse effects to people. ${ }^{91}$ The drugs were used to control the spread of disease, but scientist failed to continue with it, so there begins the development of vaccines. Currently, some of the vaccines were introduced into the market waiting for the best result among them. The fig. 10 shows the new addition and recent updates on vaccines all around the world.

\section{CONCLUSION}

This new virus outbreak has posed a threat to world's economic, medical, and public health infrastructure, particularly those in its immediate vicinity. How the virus affects our life in India will only be known with time. Following the epidemic in December 2019, several people died in various parts of the our nation and rest of the countries. In order to save the patients, many healthcare workers gave their lives. For twelve months, the whole world was shut down. The production of a vaccine to contain and kill this awful virus has improved recently. In several parts of the our nation and rest of world, ten vaccines are leading, and new additions are undergoing clinical trials but have yet to enter the market. We are hopeful that these vaccines will help to improve the current situation.

\section{REFERENCES}

1. Zhu, H., Wei, L. \& Niu, P. The novel coronavirus outbreak in Wuhan, China. glob health res policy, $2020 ; 5(6)$
2. Singhal T. A Review of Coronavirus Disease-2019 (COVID-19). Indian J Pediatr., 2020; 87(4):281286.

3. Mittal, Anshumali et al. COVID-19 pandemic: Insights into structure, function, and hACE2 receptor recognition by SARS-CoV-2. PLoS pathogens, 2020; 16(8).

4. Ksiazek, T. G., Erdman, D., Goldsmith, C. S., Zaki, S. R., Peret, T., Emery, S \& SARS Working Group. A novel coronavirus associated with severe acute respiratory syndrome. New England journal of medicine, 2003; 348(20): 1953-1966.

5. Lu, H., Stratton, C. W., \& Tang, Y. W. Outbreak of pneumonia of unknown etiology in Wuhan, China: The mystery and the miracle. Journal of medical virology, 2020; 92(4): 401.

6. Zhu, Lihua, Zhi-Gang She, Xu Cheng, JuanJuan Qin, Xiao-Jing Zhang, Jingjing Cai, Fang Lei et al. "Association of blood glucose control and outcomes in patients with COVID-19 and pre-existing type 2 diabetes." Cell metabolism, 2020; 31(6): 1068-1077.

7. Clifton, P. G., Andrew, R. J., \& Gibbs, M. E. Limited period of action of testosterone on memory formation in the chick. Journal of comparative and physiological psychology, 1982; 96(2): 212.

8. Salzberger, B., Glück, T., \& Ehrenstein, B. Successful containment of COVID-19: the WHO-Report on the COVID-19 outbreak in China 2020.

9. Silverstein, W. K., Stroud, L., Cleghorn, G. E., \& Leis, J. A. First imported case of 2019 novel coronavirus in Canada, presenting as mild pneumonia. The Lancet, 2020; 395(10225): 734.

10. Yin, Y., \& Wunderink, R. G. MERS, SARS and other coronaviruses as causes of pneumonia. Respirology, 2018; 23(2): 130-137.

11. Liu, W., Zhang, Q. I., Chen, J., Xiang, R., Song, H., Shu, S., ... \& Liu, Y. Detection of Covid-19 in children in early January 2020 in Wuhan, China. New England Journal of Medicine, 2020; 382(14): 1370-1371.

12. Rohan, T. E. Identification of women at high risk of breast cancer: an epidemiological view. Australian family physician, 1982; 11(12): 959-963.

13. Phan, D. H. B., \& Narayan, P. K. Country responses and the reaction of the stock market to COVID-19-A preliminary exposition. Emerging Markets Finance and Trade, 2020; 56(10): 21382150.

14. Tease, C. Radiation-induced chromosome nondisjunction in acolytes stimulated by different doses of super ovulating hormones. Mutation research, 1982; 105(1/2): 95-100. 
15. Ran, L., Chen, X., Wang, Y., Wu, W., Zhang, L., \& Tan, X. Risk factors of healthcare workers with coronavirus disease 2019: a retrospective cohort study in a designated hospital of Wuhan in China. Clinical Infectious Diseases, 2020; 71(16): 2218-2221.

16. Cyranoski, D. Profile of a killer: the complex biology powering the coronavirus pandemic. Nature, 2020; 581(7806): 22-27.

17. Jia, J., Ding, J., Liu, S., Liao, G., Li, J., Duan, B \& Zhang, R. Modelling the control of COVID-19: impact of policy interventions and meteorological factors. 2020. arXiv preprint arXiv:2003.02985.

18. Wan, S., Xiang, Y. I., Fang, W., Zheng, Y., Li, B., Hu, Y \& Yang, R. Clinical features and treatment of COVID-19 patients in northeast Chongqing. Journal of medical virology, 2020; 92(7): 797-806.

19. Wang, Z., Chen, X., Lu, Y., Chen, F., \& Zhang, W. Clinical characteristics and therapeutic procedure for four cases with 2019 novel coronavirus pneumonia receiving combined Chinese and Western medicine treatment. Bioscience trends 2020.

20. Cyranoski, D. China is promoting coronavirus treatments based on unproven traditional medicines. Nature 2020.

21. D. Cyranoski, 'China is promoting coronavirus treatments based on unproven traditional medicines', Nature, 2020; 6.

22. K.W. Chan, V.T. Wong \& S.C.W. Tang 'COVID-19: An Update on the Epidemiological, Clinical, Preventive and Therapeutic Evidence and Guidelines of Integrative Chinese-Western Medicine for the Management of 2019 Novel Coronavirus Disease.', The American journal of Chinese medicine. Singapore, 2020; 48(3): 737-762.

23. K.W. Chan, V.T. Wong \& S.C.W. Tang 'COVID-19: An Update on the Epidemiological, Clinical, Preventive and Therapeutic Evidence and Guidelines of Integrative Chinese-Western Medicine for the Management of 2019 Novel Coronavirus Disease.', The American journal of Chinese medicine. Singapore, 2020; 48(3): 737-762.

24. Zhang, C., Huang, S., Zheng, F., \& Dai, Y. Controversial treatments: an updated understanding of the coronavirus disease 2019. Journal of medical virology, 2020; 92(9): 1441-1448.

25. Blaising, J., Polyak, S. J., \& Pécheur, E. I. Arbidol as a broad-spectrum antiviral: an update. Antiviral research, 2014; 107: 84-94.

26. Abdelnabi, R., Neyts, J., \& Delang, L. Towards antiviral against chikungunya virus. Antiviral research, 2015; 121: 59-68.

27. Sheahan, T. P., Sims, A. C., Leist, S. R., Schäfer, A., Won, J., Brown, A. J \& Baric, R. S. Comparative therapeutic efficacy of remdesivir and combination lopinavir, ritonavir, and interferon beta against MERS-CoV. Nature communications, 2020; 11(1): 1-14.

28. Chan, K. W., Wong, V. T., \& Tang, S. C. W. COVID-19: An update on the epidemiological, clinical, preventive and therapeutic evidence and guidelines of integrative Chinese-Western medicine for the management of 2019 novel coronavirus disease. The American journal of Chinese medicine, 2020; 48(03): 737-762.

29. Shiraki, K., \& Daikoku, T. Favipiravir, an antiinfluenza drug against life-threatening RNA virus infections. Pharmacology \& therapeutics, 2020; 209: 107512.

30. Goldhill, D. H., Te Velthuis, A. J., Fletcher, R. A., Langat, P., Zambon, M., Lackenby, A., \& Barclay, W. S. The mechanism of resistance to favipiravir in influenza. Proceedings of the National Academy of Sciences, 2018; 115(45): 11613-11618.

31. Furuta, Y., Gowen, B. B., Takahashi, K., Shiraki, K., Smee, D. F., \& Barnard, D. L. Favipiravir (T-705), a novel viral RNA polymerase inhibitor. Antiviral research, 2013; 100(2): 446454.

32. Abdelnabi, R., Neyts, J., \& Delang, L. Towards antiviral against chikungunya virus. Antiviral research, 2015; 121: 59-68.

33. Dong, L., Hu, S., \& Gao, J. Discovering drugs to treat coronavirus disease 2019 (COVID-19). Drug discoveries \& therapeutics, 2020; 14(1): 58-60.

34. K.W. Chan, V.T. Wong \& S.C.W. Tang 'COVID-19: An Update on the Epidemiological, Clinical, Preventive and Therapeutic Evidence and Guidelines of Integrative Chinese-Western Medicine for the Management of 2019 Novel Coronavirus Disease.', The American journal of Chinese medicine. Singapore, 2020; 48(3): 737-762.

35. Guo, T., Fan, Y., Chen, M., Wu, X., Zhang, L., $\mathrm{He}, \mathrm{T} \& \mathrm{Lu}, \mathrm{Z}$. Cardiovascular implications of fatal outcomes of patients with coronavirus disease 2019 (COVID-19). JAMA cardiology, 2020; 5(7): 811-818.

36. Colson, P. et al. Chloroquine and hydroxychloroquine as available weapons to fight COVID-19.', International journal of antimicrobial agents, 2020; 105932. doi: 10.1016/j.ijantimicag.2020.105932.

37. D. Cyranoski, 'China is promoting coronavirus 
treatments based on unproven traditional medicines', Nature, 2020; 6.

38. Snell, L. M., McGaha, T. L., \& Brooks, D. G. Type I interferon in chronic virus infection and cancer. Trends in immunology, 2017; 38(8): 542557.

39. Li, H. S. et al. Effect of interferon alpha and cyclosporine treatment separately and in combination on Middle East Respiratory Syndrome Coronavirus (MERS-CoV) replication in a human in-vitro and ex-vivo culture model.', Antiviral research, 2018; 155: 89-96. doi: 10.1016/j.antiviral.2018.05.007.

40. K.W. Chan, V.T. Wong \& S.C.W. Tang 'COVID-19: An Update on the Epidemiological, Clinical, Preventive and Therapeutic Evidence and Guidelines of Integrative Chinese-Western Medicine for the Management of 2019 Novel Coronavirus Disease.', The American journal of Chinese medicine. Singapore, 2020; 48(3): 737-762.

41. Jones, S. A., Scheller, J., \& Rose-John, S. Therapeutic strategies for the clinical blockade of IL-6/gp130 signalling. The Journal of clinical investigation, 2011; 121(9): 3375-3383.

42. Ramamoorthy, S., \& Cidlowski, J. A. Corticosteroids: mechanisms of action in health and disease. Rheumatic Disease Clinics, 2016; 42(1): 15-31.

43. Qin, Y. Y., Zhou, Y. H., Lu, Y. Q., Sun, F., Yang, S., Harypursat, V., \& Chen, Y. K. Effectiveness of glucocorticoid therapy in patients with severe coronavirus disease 2019: protocol of a randomized controlled trial. Chinese medical journal, 2020; 133(9): 1080.

44. Guo, T. et al. 'Cardiovascular Implications of Fatal Outcomes of Patients With Coronavirus Disease 2019 (COVID-19).', JAMA cardiology, 2020; 5(7): 811-818. doi: 10.1001/ jamacardio.2020.1017.

45. Hu, H., Ma, F., Wei, X., \& Fang, Y. Coronavirus fulminant myocarditis treated with glucocorticoid and human immunoglobulin. European heart journal, 2021; 42(2): 206-206.

46. Zhang, C., Huang, S., Zheng, F., \& Dai, Y. Controversial treatments: an updated understanding of the coronavirus disease, Journal of medical virology, 2020; 92(9): 14411448.

47. Jain, J., Kumar, A., Narayanan, V., Ramaswamy, R. S., Sathiyarajeswaran, P., Devi, M. S \& Sunil, S. Antiviral activity of ethanolic extract of Nilavembu Kudineer against dengue and chikungunya virus through in vitro evaluation. Journal of Ayurveda and integrative medicine, 2020; 11(3), 329-335.
48. ASHP 'American Society of Health-System Pharmacists', ASHP Covid-19 Resoruce Center, 2021; 150.

49. J. Robinson 'Everything you need to know about the COVID-19 therapy trials', Pharmaceutical journal, 2021.

50. Sheahan, T. P., Sims, A. C., Graham, R. L., Menachery, V. D., Gralinski, L. E., Case, J. B \& Baric, R. S. Broad-spectrum antiviral GS-5734 inhibits both epidemic and zoonotic coronaviruses. Science translational medicine, 2017; 9: (396).

51. De Wit, E., Feldmann, F., Cronin, J., Jordan, R., Okumura, A., Thomas, T \& Feldmann, H. Prophylactic and therapeutic remdesivir (GS5734) treatment in the rhesus macaque model of MERS-CoV infection. Proceedings of the National Academy of Sciences, 2020; 117(12): 6771-6776.

52. A. Shukla 'COVID-19 treatment update: Here is a list of all drugs used in India; their pros and cons', CNBC TV18 (2020)

53. Barnagarwala, T. 'Explained: The drugs India is fighting Covid-19 with', Indian Express, June (2020)

54. J. Robinson 'Everything you need to know about the COVID-19 therapy trials', Pharmaceutical journal, 2021.

55. T.J. Stokkermans et al. 'Chloroquine And Hydroxychloroquine Toxicity.', in. Treasure Island (FL), 2020.

56. Park, T. Y., Jang, Y., Kim, W., Shin, J., Toh, H. T., Kim, C. H \& Kim, K. S. Chloroquine modulates inflammatory autoimmune responses through Nurr1 in autoimmune diseases. Scientific reports, 2019; 9(1): 1-11.

57. Hong Kong Medical Association. Hong Kong medical journal: Xianggang yi xue za zhi 1995.

58. J. Robinson 'Everything you need to know about the COVID-19 therapy trials', Pharmaceutical journal, 2021.

59. Mitjà, O., Corbacho-Monné, M., Ubals, M., Alemany, A., Suñer, C., Tebé, C \& Clotet, B. A cluster-randomized trial of hydroxychloroquine for prevention of Covid-19. New England Journal of Medicine 2020.

60. Rajasingham, R., Bangdiwala, A. S., Nicol, M. R., Skipper, C. P., Pastick, K. A., Axelrod, M. L \& COVID PREP team Abassi Mahsa Balster Andrew Collins Lindsey B Drobot Glen Krakower Douglas S Lother Sylvain A MacKay Dylan S Meyer-Mueller Cameron Selinsky Stephen Solvason Dayna Zarychanski Ryan Zash Rebecca. Hydroxychloroquine as preexposure prophylaxis for coronavirus disease 2019 (COVID-19) in healthcare workers: a 
randomized trial. Clinical Infectious Diseases, 2021; 72(11): e835-e843.

61. Cavalcanti, A. B., Zampieri, F. G., Rosa, R. G., Azevedo, L. C., Veiga, V. C., Avezum, A \& Berwanger, O. Hydroxychloroquine with or without azithromycin in mild-to-moderate Covid-19. New England Journal of Medicine, 2020; 383(21): 2041-2052.

62. Skipper, C. P., Pastick, K. A., Engen, N. W., Bangdiwala, A. S., Abassi, M., Lofgren, S. M \& Boulware, D. R. Hydroxychloroquine in nonhospitalized adults with early COVID-19: a randomized trial. Annals of internal medicine, 2020; 173(8): 623-631.

63. Chowdhury, M. S., Rathod, J., \& Gernsheimer, J. A rapid systematic review of clinical trials utilizing chloroquine and hydroxychloroquine as a treatment for COVID-19. Academic Emergency Medicine, 2020; 27(6): 493-504.

64. Barnagarwala, T. 'Explained: The drugs India is fighting Covid-19 with', INDIAN Express, 2020.

65. J. Robinson 'Everything you need to know about the COVID-19 therapy trials', Pharmaceutical journal, 2021.

66. A. Shukla 'COVID-19 treatment update: Here is a list of all drugs used in India; their pros and cons', CNBC TV18, 2020.

67. Barnagarwala, T. 'Explained: The drugs India is fighting Covid-19 with', INDIAN Express, 2020.

68. A. Shukla 'COVID-19 treatment update: Here is a list of all drugs used in India; their pros and cons', CNBC TV18, 2020.

69. J. Robinson 'Everything you need to know about the COVID-19 therapy trials', Pharmaceutical journal, 2021.

70. O. Hermine et al. 'Effect of Tocilizumab vs Usual Care in Adults Hospitalized With COVID-19 and Moderate or Severe Pneumonia: A Randomized Clinical Trial', JAMA Internal Medicine, 2021; 181(1): 32-40.

71. Barnagarwala, T. 'Explained: The drugs India is fighting Covid-19 with', INDIAN Express, 2020.

72. Horby, P., \& Landray, M. No clinical benefit from use of lopinavir-ritonavir in hospitalised COVID-19 patients studied in Recovery, 2020.

73. Hung, I. F. N., Lung, K. C., Tso, E. Y. K., Liu, R., Chung, T. W. H., Chu, M. Y \& Yuen, K. Y. Triple combination of interferon beta-1b, lopinavir-ritonavir, and ribavirin in the treatment of patients admitted to hospital with COVID-19: an open-label, randomised, phase 2 trial. The Lancet, 2020; 395(10238): 1695-1704.

74. Cao, B., Wang, Y., Wen, D., Liu, W., Wang, J., Fan, G \& Wang, C. A trial of lopinavir-ritonavir in adults hospitalized with severe Covid-19. New England Journal of Medicine 2020.
75. J. Robinson 'Everything you need to know about the COVID-19 therapy trials', Pharmaceutical journal, 2021.

76. Barnagarwala, T. 'Explained: The drugs India is fighting Covid-19 with', INDIAN Express, 2020.

77. J. Robinson 'Everything you need to know about the COVID-19 therapy trials', Pharmaceutical journal, 2021.

78. Tomazini, B. M., Maia, I. S., Cavalcanti, A. B., Berwanger, O., Rosa, R. G., Veiga, V. C \& COALITION COVID-19 Brazil III Investigators. Effect of dexamethasone on days alive and ventilator-free in patients with moderate or severe acute respiratory distress syndrome and COVID-19: the CoDEX randomized clinical trial. Jama, 2020; 324(13): 1307-1316.

79. Horby 'Dexamethasone in Hospitalized Patients with Covid-19- Preliminary Report', New England Journal of Medicine. Massachusetts Medical Society. 2020. doi: 10.1056/ NEJMoa2021436.

80. Barnagarwala, T. 'Explained: The drugs India is fighting Covid-19 with', INDIAN Express, 2020.

81. Malani, A. N., Sherbeck, J. P., \& Malani, P. N. Convalescent plasma and COVID-19. Jama, 2020; 324(5): 524-524.

82. Libster, R. et al. 'Early High-Titer Plasma Therapy to Prevent Severe Covid-19 in Older Adults', New England Journal of Medicine. Massachusetts Medical Society, 2021. doi: 10.1056/NEJMoa2033700.

83. Li, H. S., Kuok, D. I., Cheung, M. C., Ng, M. M., Ng, K. C., Hui, K. P \& Nicholls, J. M. Effect of interferon alpha and cyclosporine treatment separately and in combination on Middle East Respiratory Syndrome Coronavirus (MERS$\mathrm{CoV}$ ) replication in a human in-vitro and ex-vivo culture model. Antiviral research, 2018; 155: 89-96.

84. Johnson, A. F., \& Roberto, K. J. The COVID-19 pandemic: Time for a universal basic income?. Public Administration and Development 2020.

85. Johnson, A. F., Roberto, K. J., \& Rauhaus, B. M. Policies, politics and pandemics: course delivery method for US higher educational institutions amid COVID-19. Transforming Government: People, Process and Policy 2021.

86. Roberto, K. J., Johnson, A. F., \& Rauhaus, B. M. Stigmatization and prejudice during the COVID-19 pandemic. Administrative Theory \& Praxis, 2020; 42(3): 364-378.

87. Khan, M. A., Kadry, S., Parwekar, P., Damaševièius, R., Mehmood, A., Khan, J. A., \& Naqvi, S. R. Human gait analysis for osteoarthritis prediction: a framework of 
deep learning and kernel extreme learning machine. Complex \& Intelligent Systems, 2021; 1-19.

88. Sarwar, H., Akhtar, H., Naeem, M. M., Khan, J. A., Waraich, K., Shabbir, S \& Khurshid, Z. Covid-19 Pandemic and Challenges of Dentistry: Self-Reported Effectiveness of e-Learning Classes during COVID-19 Pandemic: A NationWide Survey of Pakistani Undergraduate Dentistry Students. European Journal of Dentistry, 2020; 14(Suppl 1), S34.

89. Callaway, E., Cyranoski, D., Mallapaty, S., Stoye, E., \& Tollefson, J. The coronavirus pandemic in five powerful charts 2020 .

90. Vaidyanathan, G. Scientists criticize use of unproven COVID drugs in India. Nature, 2020; 187-188.

91. Heldman, M. R., Kates, O. S., Safa, K., Kotton, C. N., Georgia, S. J., Steinbrink, J. M \& Zurabi, L. Covid-19 in hospitalized lung and non-lung solid organ transplant recipients: a comparative analysis from a multicenter study. American Journal of Transplantation 2021.

92. Hausmann, J. S., Kennedy, K., Simard, J. F., Liew, J. W., Sparks, J. A., Moni, T. T \& Kodek, M. A. Immediate effect of the COVID-19 pandemic on patient health, health-care use, and behaviours: results from an international survey of people with rheumatic diseases. The Lancet Rheumatology 2021. 